\title{
RFLP of rRNA genes and sequencing of the 16S-23S rDNA intergenic spacer region of ammonia-oxidizing bacteria: a phylogenetic approach
}

\author{
Ågot Aakra, Janne B. Utåker and Ingolf F. Nes
}

\author{
Laboratory of Microbial \\ Gene Technology, \\ Department of \\ Biotechnological Sciences, \\ Agricultural University of \\ Norway, PO Box 5051, \\ $\mathrm{N}-1432$ Ås, Norway
}

\author{
Author for correspondence: Ingolf F. Nes. Tel: +4764949471 . Fax: +4764941465. \\ e-mail: bioifn@nlh10.nlh.no
}

\begin{abstract}
It has been established that 165 rRNA gene-based phylogeny gives a low resolution between members of the chemoautotrophic ammonia-oxidizing bacteria (AOB) belonging to the $\beta$-subclass of the Proteobacteria. In this study, 12 isolates of AOB were ribotyped, and the sequences of the 165-23S rDNA intergenic spacer region (ISR) were determined and used in a phylogenetic study. 165 and 235 rDNA ribotyping revealed that the $A O B$ studied contain only one rrn operon per genome, in contrast to most bacteria, which have 5-10 copies of the rRNA genes per genome. It is likely that the presence of only one set of rRNA genes is related to the slow growth of the AOB. The 165 and 235 rRNA genes of the AOB were shown to be arranged in the classical way: a 165 rRNA gene, an ISR and a 235 rRNA gene. Despite the close phylogenetic relationship among the $A O B$, the relative location of the rRNA genes in the genome appears to vary considerably. The size of the ISR was approximately 400 bp in the Nitrosomonas isolates and 645-694 bp in the Nitrosospira isolates, suggesting a species-specific size difference in the ISR. The ISR contained two potential tRNA genes in the $5^{\prime}$ end in all isolates studied. The similarity values between the ISR sequences of the AOB are low (42.9-96.2\%) compared with the 165 rDNA sequence similarity values, and therefore the ISR sequences are valuable as a complementary phylogenetic tool in combination with 165 rRNA gene sequences. The phylogenetic analysis of the AOB based on ISR sequences confirms the 165 rRNA gene-based phylogeny but has the benefit of giving a higher resolution.
\end{abstract}

Keywords: chemoautotrophic ammonia-oxidizing bacteria, copy number of rRNA genes, 16S and 23S rDNA ribotyping, 16S-23S rDNA intergenic spacer region

\section{INTRODUCTION}

The ammonia-oxidizing bacteria (AOB) constitute a physiologically distinct group of bacteria. They are aerobic, Gram-negative and obligate chemoautotrophs, obtaining energy by oxidation of ammonia to nitrite and assimilating $\mathrm{CO}_{2}$ via the Calvin cycle. The AOB are ecologically important, being the only group of organisms that oxidize ammonia to nitrite in

\footnotetext{
Abbreviations: AOB, ammonia-oxidizing bacteria; ISR, 16S-23S rDNA intergenic spacer region.

The EMBL accession numbers for the 165 rDNA sequences and ISR sequences determined in this paper are AJ005543-AJ005558 (see Table 1).
}

significant amounts, and they appear to be present in all environments in which nitrogen is mineralized. Isolation and maintenance of $\mathrm{AOB}$ is laborious and tedious because of slow growth, a low cell yield and the risk of overgrowth by heterotrophic organisms in both enriched and pure cultures (Belser, 1979; Koops \& Möller, 1992; Watson et al., 1989). Therefore, molecular techniques are well-suited for the study of these bacteria.

Among the many important factors that may affect the growth rate of a bacterium is the number of ribosomes available in the cell. The production of rRNA is determined by the cell's overall demand for proteins, via an array of complex transcriptional regulatory 
mechanisms. In most bacteria, there are 5-10 copies of the rrn operon, but in, for example, Rickettsia, Borrelia, Mycobacterium, Mycoplasma and Archaea only one or two $r r n$ alleles have been reported (Bercovier et al., 1986; Pang \& Winkler, 1993; Schwartz et al., 1992). The nitrite-oxidizing bacteria Nitrobacter, belonging to the $\alpha$-subclass of the Proteobacteria, have also been shown to contain only one copy of the rrn operon (Navarro et al., 1992a). These bacteria, which are commonly associated with, but not phylogenetically related to, the AOB, are capable of both autotrophic and heterotrophic growth (Teske $e t$ al., 1994; Watson et al., 1989). Normally, the gene organization of bacterial rRNA gene clusters is in the order $5^{\prime}-16 \mathrm{~S}-23 \mathrm{~S}-5 \mathrm{~S}-3^{\prime}$. The length of the $16 \mathrm{~S}-23 \mathrm{~S}$ rRNA gene intergenic spacer regions (ISRs), in which tRNA-encoding genes can frequently be found, varies considerably between species (200-1500 bp) (Gürtler \& Stanisich, 1996).

The classification of organisms within the AOB group previously relied mostly on morphological characters, dividing the AOB into five genera (Koops \& Möller, 1992; Watson et al., 1989). More recently, phylogenetic studies (based on 16S rRNA gene sequences) of the AOB in the $\beta$-subclass of the Proteobacteria have revealed that these bacteria are very closely related (Head et al., 1993; Pommerening-Röser et al., 1996; Teske et al., 1994; Utåker et al., 1995) and consist of three genera only (Head et al., 1993, 1995; Teske et al., 1994; Utåker et al., 1995). The 16S rDNA sequence similarity among different AOB is so high (occasionally more than $99 \%$ within the genus Nitrosospira) that detailed phylogenetic information on these bacteria has not been obtained (Head et al., 1993; Teske et al., 1994; Utåker et al., 1995). The low 16S rDNA similarity values and the large phenotypic differences of the AOB in the $\beta$-subclass of the Proteobacteria prompted the application of alternative phylogenetic tools to classify the AOB. In this study, two highresolution techniques have been applied to 12 isolates of $\mathrm{AOB}$ : ribotyping and sequencing of the $16 \mathrm{~S}-23 \mathrm{~S}$ rDNA ISR.

Ribotyping (RFLP of rRNA genes) is a technique that combines restriction enzyme digestion of the total genomic DNA with a Southern analysis, in which rRNA gene-specific DNA probes are used. The hybridization pattern obtained is characteristic for each organism. Ribotyping determines the multiplicity, the arrangement and the relative location of rRNA genes in bacterial genomes (Rudner et al., 1994). Ribotyping patterns also contain taxonomic information.

Sequencing of the 16S-23S rDNA ISR has been suggested as an approach for the typing and identification of bacteria at both the species and the strain level (Barry et al., 1991; Gürtler \& Stanisich, 1996). The ISR can be amplified by PCR, using general bacterial 16S rRNA gene primers complementary to conserved sequences flanking the ISR. In contrast to the rRNA gene-encoding sequences, the ISRs are under minimal selective pressure during evolution and are therefore less conserved. According to LeblondBourget et al. (1996), the evolutionary rate of the ISR is assumed to be 10 times greater than the evolutionary rate of the $16 \mathrm{~S}$ rDNA. The use of ISR sequences as a phylogenetic tool is therefore limited to lower taxonomic levels, and only recent evolutionary events can be revealed. 16S rRNA gene sequences may be too conserved for the differentiation between closely related bacteria. The ISRs have been shown to vary considerably in both sequence and size between strains, species and genera, and even between distinct $r r n$ operons within one bacterium (reviewed by Gürtler \& Stanisich, 1996). Based on diversities and similarities between ISR sequences, it will be possible to construct species- and strain-specific oligonucleotides that can be used to detect bacteria in their natural environments (Barry et al., 1991).

In this work, 12 isolates of AOB were examined by ribotyping and sequencing of the 16S-23S rDNA ISR. The copy number of rRNA genes is discussed in relation to growth rate, and the ribotyping patterns of the various isolates are analysed with respect to number and relative location of rRNA genes. A phylogeny based on ISR sequences is compared with a 16S rDNA-based phylogeny, considering both the resolution and branching of the phylogenetic trees.

\section{METHODS}

Bacterial isolates and culture conditions. AOB were grown in the dark, at room temperature in a liquid ammonium medium $\left[3.78 \mathrm{mM}\left(\mathrm{NH}_{4}\right)_{2} \mathrm{SO}_{4}\right]$, as described previously (Donaldson \& Henderson, 1989; MacDonald \& Spokes, 1980). The nomenclature and origin of the isolates studied are given in Table 1.

Isolation of DNA. For ribotyping, cells were harvested by centrifugation, washed with TE buffer ( $\mathrm{pH} \mathrm{8.0)}$ ), resuspended in $0.2 \mathrm{M}$ Tris $/ \mathrm{HCl}, 20 \mathrm{mM}$ EDTA and lysed with lysozyme/ SDS. DNA was extracted with phenol-chloroform and precipitated with ethanol at $-20^{\circ} \mathrm{C}$ overnight (Sambrook et al., 1989).

For PCR, cells were harvested by centrifugation and DNA was isolated using liquid nitrogen and boiling water in a freeze-thaw method described by Head et al. (1993) and modified by Utåker \& Nes (1998).

Selection of restriction enzymes for ribotyping. Several restriction enzymes for $16 \mathrm{~S}$ rDNA ribotyping were selected on the basis of available 16S rDNA sequence data from $\mathrm{AOB}$ and tested in a control digestion of amplified $16 \mathrm{~S}$ rDNA from the AOB studied. Restriction enzymes for $23 \mathrm{~S}$ rDNA ribotyping were selected empirically, as no $23 \mathrm{~S}$ rDNA sequences from AOB are available.

Amplification of 16S rDNA, 235 rDNA and the 16S-23S rDNA ISR. PCRs $(100 \mu \mathrm{l})$ were run with $2.5 \mathrm{U}$ Taq polymerase (Advanced Biotechnologies), $10 \mathrm{mM}$ Tris $/ \mathrm{HCl}(\mathrm{pH} 8 \cdot 3$ ), $50 \mathrm{mM} \mathrm{KCl}, 1.5 \mathrm{mM} \mathrm{MgCl}, 1$ or $2 \%(\mathrm{v} / \mathrm{v})$ formamide, $200 \mu \mathrm{M}$ dNTP, $1 \mu \mathrm{M}$ each primer and $1-2 \mu \mathrm{l}$ genomic DNA, prepared as described above. Reaction mixtures were covered with mineral oil (Sigma), and amplifications were performed in a model PTC-150 minicycler (MJ Research). 
Table 1. Details of the $A O B$ isolates studied

\begin{tabular}{|c|c|c|c|c|}
\hline \multirow[t]{2}{*}{ Isolate } & \multirow[t]{2}{*}{ Origin } & \multirow[t]{2}{*}{ Reference } & \multicolumn{2}{|c|}{ EMBL accession no. } \\
\hline & & & 16S rDNA & ISR \\
\hline Nitrosospira sp. AF & Sandy loam, Zambia & Jiang (1996) & $\mathrm{X} 84658$ & AJ005552 \\
\hline Nitrosospira sp. B6 & $\begin{array}{l}\text { Pebbles, sewage treatment column, } \\
\text { Norway }\end{array}$ & Jiang (1996) & X84657 & AJ005553 \\
\hline Nitrosospira sp. $40 \mathrm{KI}$ & Loam, garden soil, Norway & Jiang (1996) & X84656 & AJ005554 \\
\hline Nitrosospira sp. L115 & Peatbog, Finland & Jiang (1996) & $\mathrm{X} 84662$ & AJ005555 \\
\hline Nitrosospira sp. III2 & Surface soil, spruce forest, Norway & Jiang (1996) & AJ000344 & AJ005556 \\
\hline Nitrosospira sp. III7 & Surface soil, spruce forest, Norway & Jiang (1996) & AJ000345 & AJ005557 \\
\hline Nitrosospira sp. A4 & Arable soil, Norway & Å. Aakra et al. (unpubl.) & AJ005543 & AJ005547 \\
\hline Nitrosospira sp. Al6 & Arable soil, Norway & Å. Aakra et al. (unpubl.) & AJ005544 & AJ005548 \\
\hline Nitrosospira sp. F3 & Concrete wall, animal house, Norway & Å. Aakra et al. (unpubl.) & AJ005545 & AJ005549 \\
\hline Nitrosospira multiformis $\mathrm{N}_{11} 3^{\mathrm{T}}$ & Type strain & NCIMB 11849 & L35509 & AJ005558 \\
\hline Nitrosomonas europaea $\mathrm{Nm} 50^{\mathrm{T}}$ & Type strain & NCIMB 11850 & M96399 & AJ005551 \\
\hline Nitrosomonas sp. F5 & Concrete wall, animal house, Norway & А.. Aakra et al. (unpubl.) & AJ005546 & AJ005550 \\
\hline
\end{tabular}

Table 2. Primers used for amplification of partial 165 rDNA and $23 S$ rDNA from AOB and from $E$. coli, as well as for amplification and sequencing of the 16S-23S rDNA ISRs in AOB

\begin{tabular}{|llccl|}
\hline Primer & \multicolumn{1}{c}{ Sequence $\left(5^{\prime} \rightarrow \mathbf{3}^{\prime}\right)$} & Target & Positions* & \multicolumn{1}{c|}{ Reference } \\
\hline $11 \mathrm{~F}$ & TGGCGAAGGCGGCCCCCTGGA & 16S rDNA & $50-70$ & Edwards et al. (1989) \\
$7 \mathrm{~F}$ & GCCTTGTACACACCGC & 16S rDNA & $1386-1401$ & Lane et al. (1985) \\
6R & AGAAAGGAGGTGATCCAGCC & 16S rDNA & $1525-1544$ & Dorsch \& Stackebrandt (1992) \\
$13 \mathrm{R}$ & GCCAAGGCATCCACCACATG & 23S rDNA & $18-37$ & Gürtler \& Stanisich (1996) \\
$23 \mathrm{SF}$ & CCGAATGGGGAAACC & 23S rDNA & $115-129$ & Gürtler \& Stanisich (1996) \\
23SR & CCTTTCCCTCACGGTA & 23S rDNA & $459-474$ & Gürtler \& Stanisich (1996) \\
ISR-F $\dagger$ & TGATAAGCGTGGGGTCGG & ISR & See Fig. 3 & This paper \\
ISR-R $\dagger$ & GATKACCCCCTGCTTGCA & ISR & See Fig. 3 & This paper \\
\hline
\end{tabular}

${ }^{*}$ E. coli numbering according to Brosius et al. (1978).

$\dagger$ The primers ISR-F and ISR-R were used for the sequencing of 16S-23S rDNA ISRs only. The sequences of these primers are based on conserved regions within the ISR of the AOB studied.

Primers used for amplification of $16 \mathrm{~S}$ rDNA were $11 \mathrm{~F}$ and 6R (Table 2). The conditions for PCR were as described previously (Utåker et al., 1995).

The primers used for amplification of a $359 \mathrm{bp}$ fragment of the 23S rRNA gene (Table 2) were slightly modified from general 23S rDNA sequences (regions 6 and 10) suggested as PCR primers by Gürtler \& Stanisich (1996). Primers were synthesized by the KEBO Lab or by Gibco BRL. Conditions for amplification of the 23S rDNA fragment were as follows: 35 cycles of $94^{\circ} \mathrm{C}$ for $1 \mathrm{~min}, 52{ }^{\circ} \mathrm{C}$ for $1 \mathrm{~min}$ and $72^{\circ} \mathrm{C}$ for $1 \mathrm{~min}$. The 16S-23S rDNA ISR was amplified by the use of the primers $7 \mathrm{~F}$ and $13 \mathrm{R}$ (Table 2 ). This region was amplified by 35 cycles of $94^{\circ} \mathrm{C}$ for $1 \mathrm{~min}, 52^{\circ} \mathrm{C}$ for $1 \mathrm{~min}$ and $72^{\circ} \mathrm{C}$ for $1 \mathrm{~min} 20 \mathrm{~s}$. In all cases, PCR products were purified using silica gel columns (QIAquick PCR purification kit; Qiagen).

Ribotyping, restriction endonuclease digestion and Southern analysis of genomic DNA. Genomic DNA was digested with different restriction enzymes (4-5 $\mu \mathrm{g}$ DNA per digest), under conditions recommended by the manufacturers (Boehringer
Mannheim or New England Biolabs). The digests were separated by electrophoresis on $1.0 \%$ agarose gels in $1 \times$ TAE buffer (pH 8.0$)$ at $2 \mathrm{~V} \mathrm{~cm}^{-1}$. The DNA was stained with ethidium bromide, visualized and transferred to nylon membranes (GeneScreen Plus; Du Pont, NEN Research Products) by Southern blotting using a 2016 Vacugene Vacuum Blotting Unit (LKB Bromma). Hybridization probes were made from Escherichia coli $16 \mathrm{~S}$ or 23S rDNA, using the primers $11 \mathrm{~F} / 6 \mathrm{R}$ and $23 \mathrm{~S}-\mathrm{F} / 23 \mathrm{~S}-\mathrm{R}$, respectively, and labelled with $\alpha^{32} \mathrm{P}$ using a commercial random priming kit (Random Primed DNA Labelling Kit; Boehringer Mannheim). Unincorporated nucleotides were removed using Pharmacia NICK columns (Pharmacia Biotech). Hybridizations were carried out as described previously (Church \& Gilbert, 1984; Lillehaug et al., 1997).

Sequencing of the 16S-235 rDNA ISR. PCR products were sequenced in both directions using, first, the primers $7 \mathrm{~F}$ and 13R (Table 2). Primers ISR-F and ISR-R (Table 2) were constructed on the basis of an alignment of the sequences thus obtained. The primers ISR-F and ISR-R are complementary to conserved regions of the ISR of the AOB 
studied. Sequencing reactions were performed using the ABI PRISM Dye Terminator Ready Reaction Kit, as specified by the manufacturer (Perkin Elmer), and sequencing was performed in an automatic sequencer (ABI Prism 377 DNA sequencer; Perkin Elmer).

Data analysis. Nucleotide sequences were analysed in the GCG program package, version 8.1 (GCG, 1994), and the Extended GCG program package, version 8.1.0 (EGCG, 1996). Sequence alignments were done using the PILEUP program in GCG (GCG, 1994). The alignments were the basis for construction of phylogenetic trees, using programs in the GCG and Extended GCG program packages (EGCG, 1996; GCG, 1994): EDNADIST, ENEIGHBOR, ECONSENSE and ESEQBOOT. All the programs were run on a Unix mainframe computer. For phylogenetic analysis of the 16S rRNA gene sequences, the sequences were adjusted to the length of the shortest sequence $(1008 \mathrm{bp})$ in the analysis. TreeView software (URL: http://taxonomy.zoology.gla.ac.uk/rod/ treeview.html) (Page, 1996) was used for visualizing the phylogenetic trees.

For identification of potential tRNA genes, the ISR sequences were analysed using the TRNASRCH program in the PC/GENE program package (Bairoch, 1993), by alignment of the sequences to known tRNA sequences (Moreira \& Amils, 1996; Rijpens et al., 1996), and by searching the nucleotide sequence database using the program FASTA (URL: http://www2.ebi.ac.uk/fasta3/; Pearson, 1990; Pearson \& Lipman, 1988).

\section{RESULTS}

\section{Ribotyping}

Most bacteria contain multiple, separate and usually identical copies of the rrn operons in the genome. The number of rRNA genes and rrn operons per genome is most easily determined by ribotyping, in which genomic DNA is digested with selected restriction enzymes, followed by identification of the rDNAcontaining fragments. Using this strategy, we determined the copy number and the relative location of the $16 \mathrm{~S}$ rRNA and 23S rRNA genes in 12 isolates of chemoautotrophic AOB.

165 rDNA ribotyping. Several restriction enzymes were tested in preliminary ribotyping experiments, from which $E c o$ RI and EcoRV were selected for the study of $16 \mathrm{~S} \mathrm{rDNA}$. The number of restriction sites for each enzyme was determined on the basis of available $16 \mathrm{~S}$ rDNA sequences and by digestion of the amplified $16 \mathrm{~S}$ rRNA gene from each isolate. In all the AOB isolates studied, one EcoRI restriction site was found in the amplified 16S rRNA gene, whereas no EcoRV restriction sites were found in the same 16S rDNA. Consequently, hybridization between a 16S rDNA probe and the EcoRI-restricted genomic DNA was expected to give two hybridization bands per copy of the gene, whereas hybridization between EcoRVdigested genomic DNA and the 16S rRNA gene probe was expected to give one hybridization band per gene copy. Both EcoRI and EcoRV gave unique and reproducible ribotyping patterns, summarized in Table 3 . The hybridization patterns revealed the presence of only one copy of the 16S rRNA gene in the genome of these bacteria, as the 16S rDNA probe hybridized to two bands of the EcoRI-restricted DNA and to one band of the EcoRV-restricted DNA. The ribotyping patterns revealed a different relative location of the 16S rRNA genes in the genomic restriction pattern.

235 rDNA ribotyping. Having established that there is only one copy of the 16S rRNA gene in the genomes of the 12 AOB studied, it was also of interest to determine the number of 23S rRNA genes, as duplicated 23S-5S rRNA genes have been reported in other bacteria (e.g. Schwartz et al., 1992).

Since no 23S rDNA sequences from AOB are available, the number of restriction sites in the 23S rDNA fragment used as a target sequence in the ribotyping assays was determined experimentally. The chosen fragment was $359 \mathrm{bp}$ and was amplified from each AOB. It was established that neither EcoRI nor EcoRV has restriction sites in this $359 \mathrm{bp}$ fragment of the $23 \mathrm{~S}$ rDNA molecule in any of the AOB isolates. Provided that only one copy of the 23S rRNA gene is present in the genomes of the AOB studied, a ribotyping analysis using these two enzymes would give one hybridization band only. Indeed, only one hybridization band appeared in both EcoRI- and EcoRV-digested genomic DNA (Table 3). These results strongly indicate that the $12 \mathrm{AOB}$ examined contain only one copy of the 23S rRNA gene, supporting the idea that these bacteria have only one $r r n$ operon.

\section{Characterization of the 16S-235 rDNA ISR}

The ISR was amplified by PCR, using primers based on conserved regions flanking the ISR. The size of the ISR was determined exactly by sequencing. The size of the ISRs of the 10 Nitrosospira isolates studied varied from $645 \mathrm{bp}$ to $694 \mathrm{bp}$, whereas the size of the ISR of the two Nitrosomonas isolates was considerably shorter: only 402 and 404 bp. Each isolate studied had a unique ISR sequence, a fact that is important when considering specific detection and identification of AOB. The degree of intrageneric ISR sequence similarity was higher than the degree of intergeneric similarity, and the overall similarity values of the ISRs varied from 42.9 to $96.2 \%$ and from 68.9 to $96.2 \%$ among the Nitrosospira spp. studied. One possible AlatRNA and one possible Ile-tRNA gene were found clustered near the $5^{\prime}$ end of the ISR in all the AOB studied. This is a common feature of the ISR in rrn operons in Gram-negative bacteria (reviewed by Gürtler \& Stanisich, 1996). The tRNA gene sequences found in the ISR of the AOB are highly conserved, i.e. there is a clear distinction between the coding and noncoding regions of the ISR.

\section{Phylogenetic analysis based on the ISR}

It was of interest to perform a phylogenetic analysis of the AOB based on the ISR sequences, as the $16 \mathrm{~S}$ rRNA gene-based phylogeny has previously been shown to have a very low resolution, owing to high 
Table 3. Approximate size (kbp) of hybridization bands obtained by ribotyping of 12 isolates of $A O B$ using restriction enzymes (a) EcoRI and (b) EcoRV

-, No data available.

\begin{tabular}{|c|c|c|c|c|c|}
\hline \multirow[t]{2}{*}{ Isolate } & \multicolumn{3}{|c|}{ EcoRI ribotyping } & \multicolumn{2}{|c|}{ EcoRV ribotyping } \\
\hline & $16 S_{1}$ & $\mathbf{N A}^{*}$ & 23S rDNA & 16S rDNA & 23S rDNA \\
\hline Nitrosospira sp. AF & $7 \cdot 3$ & $5 \cdot 3$ & $7 \cdot 3$ & $>12$ & $>12$ \\
\hline Nitrosospira sp. B6 & $5 \cdot 1$ & $3 \cdot 8$ & $5 \cdot 1$ & $2 \cdot 6$ & $3 \cdot 6$ \\
\hline Nitrosospira sp. $40 \mathrm{KI}$ & $3 \cdot 1$ & $1 \cdot 6$ & $6 \cdot 0$ & $6 \cdot 6$ & $6 \cdot 6$ \\
\hline Nitrosospira sp. L115 & $7 \cdot 4$ & $3 \cdot 3$ & $7 \cdot 4$ & $9 \cdot 0$ & $9 \cdot 0$ \\
\hline Nitrosospira sp. III2 & $8 \cdot 4$ & $3 \cdot 5$ & $8 \cdot 4$ & $8 \cdot 7$ & $8 \cdot 7$ \\
\hline Nitrosospira sp. III7 & $5 \cdot 0$ & $3 \cdot 8$ & $5 \cdot 0$ & $3 \cdot 1$ & $8 \cdot 1$ \\
\hline Nitrosospira sp. A4 & $8 \cdot 1$ & $3 \cdot 3$ & $8 \cdot 1$ & $>12$ & $>12$ \\
\hline Nitrosospira sp. Al6 & $6 \cdot 1$ & $3 \cdot 3$ & $6 \cdot 1$ & $>12$ & $>12$ \\
\hline Nitrosospira sp. F3 & - & - & - & $9 \cdot 1$ & - \\
\hline Nitrosospira multiformis $\mathrm{N}_{11} 3^{\mathrm{T}}$ & $5 \cdot 5$ & $1 \cdot 3$ & $6 \cdot 2$ & $7 \cdot 1$ & $7 \cdot 1$ \\
\hline Nitrosomonas europaea $\mathrm{Nm} 50^{\mathrm{T}}$ & $6 \cdot 5$ & $3 \cdot 3$ & $3 \cdot 3$ & $>12$ & $>12$ \\
\hline Nitrosomonas sp. F5 & $3 \cdot 0$ & $1 \cdot 6$ & - & - & - \\
\hline
\end{tabular}

* By EcoRI ribotyping two bands were obtained for each organism.
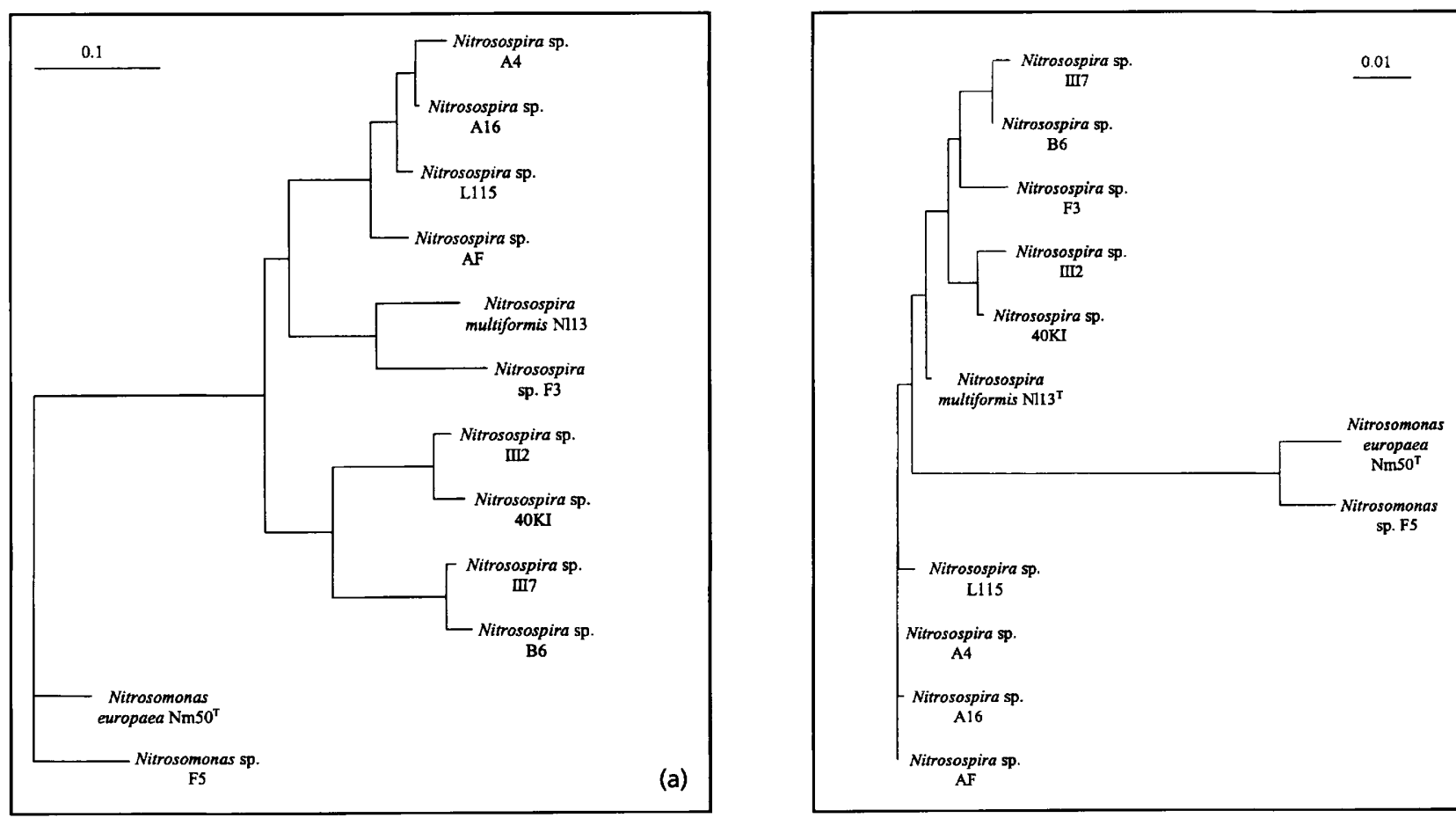

(b)

Fig. 1. Maximum-likelihood trees (Felsenstein, 1981) of (a) the 16S-23S rDNA ISR and (b) the 16S rRNA gene from the $A O B$ in this study. Bars indicate a relative distance of 0.1 in the ISR-based tree (a) and 0.01 in the 16S rRNA-gene-based tree (b). The trees were constructed using the program EDNAML in the EGCG computer program package (EGCG, 1996), which is a modified version of the PHYLIP program DNAML (Felsenstein, 1981). All sequences included were adjusted to the length of the shortest $16 \mathrm{~S}$ rRNA gene sequence (1009 bp).

sequence similarity. Phylogenetic trees constructed on the basis of the ISR sequences (Fig. 1a) were topologically quite similar to the trees constructed on the basis of $16 \mathrm{~S}$ rDNA sequences (Fig. 1b). The branching of the ISR trees was the same regardless of the method used for tree construction. The resolution, however, 
was markedly improved compared with the 16S rRNA gene-based phylogeny. The clustering of the trees constructed on the basis of 16S rRNA gene sequences has been shown to vary slightly when different algorithms are used for the phylogenetic analysis (Utåker et al., 1995), probably because of the small overall sequence differences between the 16S rRNA gene sequences. The trees in Fig. 1 were both made using the maximum-likelihood method (Felsenstein, 1981) and show the same branching patterns for 10 out of the 12 AOB examined. Nitrosospira spp. F3 and $\mathrm{N}_{113^{\mathrm{T}}}$ cluster differently in the two phylogenetic trees shown in Fig. 1. In a bootstrapped parsimony analysis with 100 replicates, the branching points occur with a considerably higher frequency for the ISR sequences than in the corresponding tree based on 16S rRNA gene sequences (not shown). The only exception is the node dividing Nitrosospira multiformis spp. $\mathrm{N} 13^{\mathrm{T}}$ and F3 from the other Nitrosospiras, which occurs with a frequency of $0 \cdot 53$. Clear conclusions on the phylogenetic position of these two AOB cannot therefore be drawn at present.

\section{DISCUSSION}

\section{Ribotyping}

Together, the results of the $E c o \mathrm{RI}$ and $E c o \mathrm{RV}$ analyses argue strongly that the AOB contain only one copy of the rRNA genes. Although some of the hybridization bands obtained by EcoRV ribotyping were large enough to contain more than one rrn operon, the combination with EcoRI ribotyping gave a clear conclusion: 16S rDNA ribotyping of EcoRI-restricted genomic DNA gave two hybridization bands per genome analysed and $23 \mathrm{~S}$ rDNA ribotyping revealed one band per genome, indicating the presence of only one rrn operon.

The size similarity of the hybridization fragments obtained by $16 \mathrm{~S}$ and $23 \mathrm{~S}$ rDNA ribotyping indicates that the 16S and 23S rRNA genes are organized tandemly. Furthermore, the fact that PCR products were obtained using primers complementary to conserved regions of the $3^{\prime}$ end of the 16S rRNA gene and $5^{\prime}$ end of the 23S rRNA gene suggests that the $16 \mathrm{~S}$ rRNA gene is located upstream of the 23S rRNA gene. It is therefore likely that the $r r n$ operons of the AOB are organized as the typical bacterial $r r n$ operons. Interestingly, the hybridization banding patterns obtained by ribotyping may also indicate a different organization of the genomes of these closely related bacteria, but this needs further studies.

Ribotyping alone cannot be used for identification of species, but, in contrast to 16S rDNA sequencing, different isolates can easily be distinguished. Since neither the phenotypical characteristics nor the 16S rRNA gene-based phylogeny of the AOB are sufficient for an unambiguous classification of the $A O B$, it is very important to establish reliable techniques with a higher resolution. Ribotyping has, in the present study, been shown to be a powerful technique for the differentiation of $\mathrm{AOB}$ isolates. However, the phylogenetic information obtained by the ribotyping patterns of AOB is limited, since only one set of rRNA genes was found. The complexity of the hybridization patterns generated is too low to give clear conclusions about their phylogeny, as has been done for bacteria with several rrn operons, e.g. pseudomonads (Brosch et al., 1996), propionibacteria (Riedl \& Britz, 1996), Bacillus spp. and E. coli spp. (Rudner et al., 1994). However, ribotyping analyses, combined with results of DNA-DNA hybridization experiments, have been used as the basis for a proposed reclassification of the $\alpha$-proteobacterium Nitrobacter, which also has only one genomic copy of the 16S rRNA gene (Navarro et al., 1992a). Judged by these facts, ribotyping seems to be a valuable supplementary tool in the study of closely related bacteria.

\section{Analysis of the 16S-23S rDNA ISR}

The ISR-based phylogeny has improved and complemented the phylogeny of the AOB based on $16 \mathrm{~S}$ rRNA gene sequences. For intrageneric and intraspecific determination of phylogenetic relationships, ISR characterization is a powerful and reliable supplementary tool. In this work, the 10 isolates of Nitrosospira were shown to have an ISR of 645-694 bp, while the two Nitrosomonas isolates studied had an ISR that was considerably shorter (approx. $400 \mathrm{bp}$ ). Although additional isolates ought to be examined, the size of the ISR appears to be a species characteristic. In the process of obtaining new isolates of AOB, such a distinct species-related difference will be very useful, for both identification and classification.

The ISR and 16S rRNA gene of the AOB seem to provide complementary phylogenetic information with different qualities. Usually, $16 \mathrm{~S}$ rDNA sequencing is a tool sufficient for inferring inter- and intrageneric relationships, but it has been shown that recently diverged species may not be distinguishable on the $16 \mathrm{~S}$ rRNA gene level (Fox et al., 1992). The analysis performed in this study leads to the conclusion that the ISR sequences from AOB provide information concerning intraspecific relations which are almost invisible in a $16 \mathrm{~S}$ rDNA-based phylogeny and allow the detection of more recently evolved diversities. For some bacteria, the sequence divergence of ISRs has prompted proposals of reclassifications (Yoon et al., 1997). Comparisons of ISRs from closely related organisms have been proposed and used as a criterion for differentiation, but it is evident that the ISR alone cannot be used to determine relationships among distantly related organisms. The high level of sequence variation, insertions and deletions in the ISR may bias the phylogenetic analysis. The ISR should be used as a tool to clarify controversial strain and species definitions, an application that is urgently needed in the study of AOB. 
PCR/RFLP analysis of the ISR has previously been used to characterize 39 isolates of Nitrobacter (Navarro et al., 1992b), in which a correlation between PCR/RFLP patterns and the origin of the isolates was revealed. Characterization of the ISR of the AOB in this work does not seem to refiect any ecological relatedness between the isolates studied. Conclusions on an ecological relevance of the phylogeny based on the ISR of these bacteria cannot yet be drawn, in contrast to what has been found in studies on $\mathrm{G}+\mathrm{C}$ contents in other AOB; some $\mathrm{G}+\mathrm{C}$ clusters are found in similar environments (Koops \& Harms, 1985).

In studies on ecological diversity of AOB, it is important to identify the organisms in situ, without the need for purification of cultures prior to an analysis. Purification of AOB cultures is tedious and difficult, and it is generally believed that there is a selection for certain AOB during this process: purified cultures therefore reflect the conditions used for isolation, rather than the actual dominance of the particular strains in the environment (Mobarry et al., 1996; Utåker \& Nes, 1998; Wagner et al., 1995). Because of this, pure cultures of $\mathrm{AOB}$ available today are considered unrepresentative of the true diversity of AOB in the environment. Recently, there have been several attempts to construct specific oligonucleotides based on 16S rDNA sequences (McCaig et al., 1994), reviewed by Utåker \& Nes (1998), with the aim of detecting AOB in various environments. As the $16 \mathrm{~S}$ rDNA sequences of most AOB are highly similar, however, it is doubtful if $16 \mathrm{~S} \mathrm{rDNA}$ sequences are best suited for the specific detection of AOB. The ISR has been considered an ideal region for the development of specific oligonucleotides, because of the extensive sequence variation (Barry et al., 1991). Specific oligonucleotides based on ISR sequences have been developed for several other bacteria (Barry et al., 1991; Graham et al., 1996; Li \& De Boer, 1995; Rijpens et al., 1996; Smart et al., 1996), but a specific detection of organisms with multiple rrn operons may be limited, because the ISR sequences may vary between different $r r n$ operons within one bacterium. In the case of AOB, however, specific oligonucleotides recognizing the ISR will be more appropriate because of the presence of a single copy of the rrn operon in the genome. Sequencing of the ISR from other representatives of AOB belonging to the $\beta$-subclass of the Proteobacteria is now being performed, in an attempt to find speciesand strain-specific oligonucleotides that can be utilized for the specific detection of AOB in the environment. Although oligonucleotides based on ISR sequences may be very useful in environmental studies on AOB, the information on ISR sequences from ecologically related organisms is limited, and, therefore the specificity of the ISR oligonucleotides must be thoroughly tested experimentally.

\section{ACKNOWLEDGEMENTS}

This work was supported by grants from the Norwegian Research Council.

\section{REFERENCES}

Bairoch, A. (1993). PC/GENE program package, release 6.80 . Department of Medical Biochemistry, University of Geneva, Switzerland.

Barry, T., Colleran, G., Glennon, M., Dunican, L. K. \& Gannon, F. (1991). The $16 \mathrm{~S} / 23 \mathrm{~S}$ ribosomal spacer region as a target for DNA probes to identify eubacteria. PCR Methods Appl 1, 51-56.

Belser, L. W. (1979). Population ecology of nitrifying bacteria. Annu Rev Microbiol 33, 309-333.

Bercovier, H., Kafri, O. \& Sela, S. (1986). Mycobacteria possess a surprisingly small number of ribosomal RNA genes in relation to the size of their genome. Biochem Biophys Res Commun 136, 1136-1141.

Brosch, R., Lefèvre, M., Grimont, F. \& Grimont, P. A. D. (1996). Taxonomic diversity of pseudomonads revealed by computer interpretation of ribotyping data. Syst Appl Microbiol 19, 541-555.

Brosius, J., Palmer, M. L., Kennedy, P. J. \& Noller, H. F. (1978). Complete nucleotide sequence of a $16 \mathrm{~S}$ ribosomal RNA gene from Escherichia coli. Proc Natl Acad Sci USA 75, 4801-4805.

Church, G. M. \& Gilbert, W. (1984). Genomic sequencing. Proc Natl Acad Sci USA 81, 1991-1995.

Donaldson, J. M. \& Henderson, G. S. (1989). A dilute medium to determine population size of ammonium oxidizers in soil. Soil Sci Soc Am 53, 1608-1611.

Dorsch, M. \& Stackebrandt, E. (1992). Some modifications in the procedure of direct sequencing of PCR amplified 16S rDNA. $J$ Microbiol Methods 16, 271-279.

Edwards, U., Rogall, T., Blocker, H., Emde, M. \& Bottger, E. C. (1989). Isolation and direct complete nucleotide determination of entire genes. Characterization of a gene coding for $16 \mathrm{~S}$ ribosomal RNA. Nucleic Acids Res 17, 7843-7853.

EGCG (1996). Program Manual for the EGCG Package, version 8.1.0, March 1996. Peter Rice, The Sanger Centre, Hinxton Hall, Cambridge CB10 1RQ, UK.

Felsenstein, J. (1993). PHYLIP (Phylogeny Inference Package) 3.572c. Department of Genetics, University of Washington, Seattle, USA.

Felsenstein, J. (1981). Evolutionary trees from DNA sequences: a maximum likelihood approach. J Mol Evol 17, 368-376.

Fox, G. E., Wisotzkey, J. D. \& Jurtshuk, P., Jr (1992). How close is close: 16S rRNA sequence identity may not be sufficient to guarantee species identity. Int J Syst Bacteriol 42, 166-170.

GCG (1994). Program Manual for the Wisconsin Package, Genetics Computer Group, version 8.1, August 1995. 575 Science Drive, Madison, WI 53711, USA.

Graham, T., Golsteyn-Thomas, E. J., Gannon, V. P. J. \& Thomas, J. E. (1996). Genus- and species specific detection of Listeria monocytogenes using polymerase chain reaction assays targeting the $16 \mathrm{~S} / 23 \mathrm{~S}$ intergenic spacer region of the rRNA operon. Can $J$ Microbiol 42, 1155-1162.

Gürtler, V. \& Stanisich, V. A. (1996). New approaches to typing and identification of bacteria using the $16 \mathrm{~S}-23 \mathrm{~S}$ rDNA spacer region. Microbiology 142, 3-16.

Head, I. M., Hiorns, W. D., Embley, T. M., McCarthy, A. J. \& Saunders, J. R. (1993). The phylogeny of autotrophic ammoniaoxidizing bacteria as determined by analysis of $16 \mathrm{~S}$ ribosomal RNA gene sequences. J Gen Microbiol 139, 1147-1153.

Head, I. M., Hiorns, W. D., Embley, T. M., McCarthy, A. J. \& Saunders, J. R. (1995). In Validation of the Publication of New 
Names and New Combinations Previously Effectively Published Outside the IJSB, List no. 54. Int J Syst Bacteriol 45, 619-620.

Jiang, Q. Q. (1996). Nitrosospira from terrestrial environments, its urease activity and nitrous oxide production. Doctor Scientarium thesis 1996:21, Agricultural University of Norway.

Koops, H.-P. \& Harms, H. (1985). Deoxyribonucleic acid homologies among 96 strains of ammonia oxidizing bacteria. Arch Microbiol 141, 214-218.

Koops, H.-P. \& Moller, U. C. (1992). The lithotrophic ammoniaoxidizing bacteria. In The Prokaryotes, pp. 2625-2637. Edited by A. Balows, H. G. Trüper, M. Dworkin, W. Harder \& K. H. Schleifer. New York: Fischer-Verlag.

Lane, D. J., Pace, B., Olsen, G. J., Stahl, D. A., Sogin, M. L. \& Pace, N. R. (1985). Rapid determination of $16 \mathrm{~S}$ ribosomal RNA sequences for phylogenetic analyses. Proc Natl Acad Sci USA 82, 6955-6959.

Leblond-Bourget, N., Philippe, H., Mangin, I. \& Decaris, B. (1996). $16 \mathrm{~S}$ rRNA and $16 \mathrm{~S}$ to $23 \mathrm{~S}$ internal transcribed spacer sequence analyses reveal inter- and intraspecific Bifidobacterium phylogeny. Int J Syst Bacteriol 46, 102-111.

Li, X. \& De Boer, S. H. (1995). Selection of polymerase chain reaction chain reaction primers from an RNA intergenic spacer region for specific detection of Clavibacter michiganensis subsp. sepedonicus. Phytopathology 85, 837-842.

Lillehaug, D., Nes, I. F. \& Birkeland, N. K. (1997). A highly efficient and stable system for site-specific integration of genes and plasmids into the phage phiLC3 attachment site (attB) of the Lactococcus lactis chromosome. Gene 188, 129-36.

McCaig, A. E., Embley, T. M. \& Prosser, J. I. (1994). Molecular analysis of enrichment cultures of marine ammonia oxidisers. FEMS Microbiol Lett 120, 363-368.

MacDonald, R. M. \& Spokes, J. R. (1980). A selective and diagnostic medium for ammonia oxidising bacteria. FEMS Microbiol Lett 8, 143-145.

Mobarry, B. K., Wagner, M., Urbain, V., Rittmann, B. E. \& Stahl, D. A. (1996). Phylogenetic probes for analyzing abundance and spatial organization of nitrifying bacteria. Appl Environ Microbiol 62, 2156-2162.

Moreira, D. \& Amils, R. (1996). PCR-mediated detection of the chemolithotrophic bacterium Thiobacillus cuprinus using $23 \mathrm{~S}$ rDNA and $16 \mathrm{~S} / 23 \mathrm{~S}$ rDNA intergenic spacer region-targeted oligonucleotide primers. FEMS Microbiol Lett 142, 289-293.

Navarro, E., Fernandez, M. P., Grimont, F., Claysjosserand, A. \& Bardin, R. (1992a). Genomic heterogeneity of the genus Nitrobacter. Int J Syst Bacteriol 42, 554-560.

Navarro, E., Simonet, P., Normand, P. \& Bardin, R. (1992b). Characterization of natural populations of Nitrobacter spp. using PCR/RFLP analysis of the ribosomal intergenic spacer. Arch Microbiol 157, 107-115.

Page, R. D. M. (1996). TreeView: an application to display phylogenetic trees on personal computers. Comput Appl Biosci 12, 357-358.

Pang, H. \& Winkler, H. H. (1993). Copy number of the 16S rRNA gene in Rickettsia prowazekii. J Bacteriol 175, 3893-3896.
Pearson, W. R. (1990). Rapid and sensitive sequence comparison with FASTP and FASTA. Methods Enzymol 183, 63-98.

Pearson, W. R. \& Lipman, D. J. (1988). Improved tools for biological sequence comparison. Proc Natl Acad Sci USA 85, 2444-2448.

Pommerening-Roser, A., Rath, G. \& Koops, H.-P. (1996). Phylogenetic diversity within the genus Nitrosomonas. Syst Appl Microbiol 19, 344-351.

Riedl, K.-H. J. \& Britz, T. J. (1996). Justification of the 'classical' Propionibacterium species concept by ribotyping. Syst Appl Microbiol 19, 370-380.

Rijpens, N. P., Jannes, G., Van Asbroeck, M., Rossau, R. \& Herman, L. M. F. (1996). Direct detection of Brucella spp. in raw milk by PCR and reverse hybridization with $16 \mathrm{~S}-23 \mathrm{~S}$ rRNA spacer probes. Appl Environ Microbiol 62, 1683-1688.

Rudner, R., Studamire, B. \& Jarvis, E. D. (1994). Determination of restriction fragment length polymorphism in bacteria using ribosomal RNA genes. Methods Enzymol 235, 184-196.

Sambrook, J., Fritsch, E. F. \& Maniatis, T. (1989). Molecular Cloning : a Laboratory Manual, 2nd edn. Cold Spring Harbor, NY: Cold Spring Harbor Laboratory.

Schwartz, J. J., Gazumyan, A. \& Schwartz, I. (1992). rRNA gene organization in the Lyme disease spirochete, Borrelia burgdorferi. J Bacteriol 174, 3757-3765.

Smart, C. D., Schneider, B., Blomquist, C. L., Guerra, L. J., Harrison, N. A., Ahrens, U., Lorenz, K. H., Seemuller, E. \& Kirkpatrick, B. C. (1996). Phytoplasma-specific PCR primers based on sequences of the 16S-23S rRNA spacer region. Appl Environ Microbiol 62, 2988-2993.

Teske, A., Alm, E., Regan, J. M., Toze, S., Rittmann, B. E. \& Stahl, D. A. (1994). Evolutionary relationships among ammonia- and nitrite-oxidizing bacteria. J Bacteriol 176, 6623-6630.

Utåker, J. B. \& Nes, I. F. (1998). A qualitative evaluation of the published oligonucleotides specific for the 16S rDNA gene sequences of the ammonia-oxidizing bacteria. Syst Appl Microbiol 21, 72-88.

Utåker, J. B., Bakken, L., Jiang, Q. Q. \& Nes, I. F. (1995). Phylogenetic analysis of seven new isolates of ammoniaoxidizing bacteria based on 16S rRNA gene sequences. Syst Appl Microbiol 18, 549-559.

Wagner, M., Rath, G., Amann, R., Koops, H.-P. \& Schleifer, K. H. (1995). In-situ identification of ammonia-oxidizing bacteria. Syst Appl Microbiol 18, 251-264.

Watson, S. W., Bock, E., Harms, H., Koops, H.-P. \& Hooper, A. B. (1989). Nitrifying bacteria. In Bergey's Manual of Systematic Bacteriology, pp. 1808-1834. Edited by J. T. Staley, M. P. Bryant, N. Pfenning \& J. G. Holt. Baltimore: Williams \& Wilkins.

Yoon, J.-H., Lee, S. T., Kim, S.-B., Goodfellow, M. \& Park, Y.-H. (1997). Inter- and intraspecific genetic analysis of the genus Saccharomonospora with $16 \mathrm{~S}$ to $23 \mathrm{~S}$ ribosomal DNA (rDNA) and $23 \mathrm{~S}$ to $5 \mathrm{~S}$ rDNA internally transcribed spacer sequences. Int $J$ Syst Bacteriol 47, 661-669. 